\title{
POSTN Gene
}

National Cancer Institute

\section{Source}

National Cancer Institute. POSTN Gene. NCI Thesaurus. Code C101422.

This gene plays a role in both heparin binding and cell adhesion. 